\title{
Optimization of particle bombardment parameters for the genetic transformation of Brazilian maize inbred lines
}

\author{
Caroline Pereira Petrillo(1), Newton Portilho Carneiro(2), Antônio Álvaro Corsetti Purcino(2), \\ Carlos Henrique Siqueira Carvalho(3), José Donizeti Alves ${ }^{(1)}$ and Andréa Almeida Carneiro ${ }^{(2)}$
}

\begin{abstract}
(1)Universidade Federal de Lavras, Departamento de Fisiologia Vegetal, Caixa Postal 37, CEP 37200-000 Lavras, MG, Brazil. E-mail: carolpetrillo@terra.com.br, jdalves@ufla.br (2)Embrapa Milho e Sorgo, Caixa Postal 151, CEP 35701-970 Sete Lagoas, MG, Brazil. E-mail: newtonc@cnpms.embrapa.br, corsetti@cnpms.embrap.br, andreac@cnpms.embrapa.br (3)Embrapa Café, Alameda do Café, no 1.000, Jardim Andere, CEP 37026-400 Varginha, MG, Brazil. E-mail: carlos@varginha.br
\end{abstract}

\begin{abstract}
The objective of this work was to develop a genetic transformation system for tropical maize genotypes via particle bombardment of immature zygotic embryos. Particle bombardment was carried out using a genetic construct with bar and uidA genes under control of CaMV35S promoter. The best conditions to transform maize tropical inbred lines L3 and L1345 were obtained when immature embryos were cultivated, prior to the bombardment, in higher osmolarity during 4 hours and bombarded at an acceleration helium gas pressure of 1,100 psi, two shots per plate, and a microcarrier flying distance of $6.6 \mathrm{~cm}$. Transformation frequencies obtained using these conditions ranged from 0.9 to $2.31 \%$. Integration of foreign genes into the genome of maize plants was confirmed by Southern blot analysis as well as bar and uidA gene expressions. The maize genetic transformation protocol developed in this work will possibly improve the efficiency to produce new transgenic tropical maize lines expressing desirable agronomic characteristics.
\end{abstract}

Index terms: Zea mays, ammonium glufosinate, beta-glucuronidase, immature embryos, phosphinotricin acetyl transferase, plant transformation.

\section{Otimização dos parâmetros de bombardeamento de partículas para a transformação genética de linhagens brasileiras de milho}

\begin{abstract}
Resumo - O objetivo deste trabalho foi desenvolver um sistema de transformação genética para genótipos tropicais de milho pelo bombardeamento de embriões imaturos com micropartículas. O bombardeamento com partículas foi realizado utilizando-se uma construção gênica contendo os genes bar e uidA sob o controle do promotor CaMV35S. As melhores condições para transformação das linhagens de milho tropical L3 e L1345 foram obtidas após o cultivo de embriões imaturos durante 4 horas, antes do bombardeamento, em alta osmolaridade, e bombardeados com a pressão de 1.100 psi de gás hélio, dois tiros por placa e uma distância de vôo da micropartícula de $6,6 \mathrm{~cm}$. As freqüências de transformação obtidas variaram entre 0,9 e $2,31 \%$. A integração dos genes heterólogos no genoma das plantas transgênicas de milho foi confirmada por análises de Southern blot e expressão dos genes bar e uidA. O protocolo de transformação genética de milho desenvolvido neste estudo irá aumentar, provavelmente, a eficiência de produção de novas linhagens tropicais de milho expressando características agronômicas desejáveis.
\end{abstract}

Termos para indexação: Zea mays, glufosinato de amônio, beta-glucuronidase, embriões imaturos, fosfinotricina acetil transferase, transformação de plantas.

\section{Introduction}

The enormous progress achieved by molecular and cellular biology in recent years has generated a new understanding for many basic genetic concepts and biochemical mechanisms, allowing the emergence of improved strategies for breeding and cultivar development. Among the new generated technologies, plant transformation is an important tool for the genetic manipulation and improvement of crop species (Carneiro et al., 2000).
As maize is a major commodity in international agriculture and an important source of protein and energy for human and livestock nutrition, it has been one of the prime targets for genetic manipulation. However, most studies on maize transformation have utilized genotypes adapted to temperate zones (Frame et al., 2000). The application of this technology in the tropics was delayed due to additional steps of backcrossing tropical lines with transgenic temperate lines. Therefore, to accelerate the process it is essential to develop technologies for the 
production of transgenic tropical and subtropical maize lines (Brettschneider et al., 1997; Bohorova et al., 1999).

To transfer foreign genes into the maize genome, various reports have shown that microprojectile bombardment is a successful technique (Klein et al., 1988; Brettschneider et al., 1997; Frame et al., 2000; Lorence \& Verpoorte 2004; Herrera-Estrella et al., 2005).

Immature embryo is a suitable primary explant from which pollinated maize plants can be regenerated. Different tropical maize genotypes are able to form Type I as well as Type II callus from immature embryo cultures (Carvalho et al., 1997; Bohorova et al., 1999; Frame et al., 2006), and according to Brettschneider et al. (1997), both callus types are suitable target for biolistic transformation.

Reporter genes such as the ones that code for betaglucuronidase - GUS (uidA) - and green fluorescent protein $(g f p)$ together with the herbicide selection gene, phosphinothricin acetyltransferase (pat) (Brettschneider et al., 1997; Bohorova et al., 1999; Jeoung et al., 2002; Tadesse et al., 2003), have been effectively used to optimize genetic transformation protocols.

The objective of this work was to develop a genetic transformation system for tropical maize genotypes via particle bombardment of immature zygotic embryos.

\section{Materials and Methods}

Immature embryos, between 1 and $2 \mathrm{~mm}$ length (8-16 days after pollination), were harvested from plants grown at Embrapa Milho e Sorgo, Sete Lagoas, MG, Brazil. Seeds used in these experiments were from the L1345 and L3 tropical maize inbred lines, with high capacities for plant regeneration (Carvalho et al., 1997) and favorable agronomic characteristics.

Ears for embryo extraction were surface-sterilized using half-strength liquid commercial bleach (1:1, bleach:water) and $0.01 \%$ Tween 20 , during 40 minutes and then rinsed three times with sterilized distilled water. Immature embryos were isolated and cultivated scutellum-side up onto the surface of BCI callus induction medium - N6 salts and N6 vitamins (Chu et al., 1975), $100 \mathrm{mg} \mathrm{L}^{-1}$ myo-inositol, $2.87 \mathrm{~g} \mathrm{~L}^{-1}$ proline, $200 \mathrm{mg} \mathrm{L}^{-1}$ hydrolyzed casein, $30 \mathrm{~g} \mathrm{~L}^{-1}$ sucrose, $2.5 \mathrm{~g} \mathrm{~L}^{-1}$ Phytagel, $1.7 \mathrm{mg} \mathrm{L}^{-1}$ silver nitrate, $3.3 \mathrm{mg} \mathrm{L}^{-1}$ dicamba. $\mathrm{pH}$ was adjusted to 5.8 with $1 \mathrm{~N}$ potassium hydroxide prior autoclaving. Cultures were kept in Petri dishes $(100 \times 25 \mathrm{~mm})$ at $27^{\circ} \mathrm{C}$ and grown in the dark for callus initiation and maintenance.

The plasmid used in this work, pCAMBIA 3301 (Cambia, Canberra, Australia), contains the CaMV35S promoter directing the synthesis of both E. coli beta-glucuronidase (Jefferson et al., 1987), and phosphinothricin acetyltransferase (PAT). Plasmid DNA used in bombardment experiments was purified by a cesium chloride gradient according to Sambrook et al. (1989).

Immature embryos, cultured during five days on $\mathrm{BCI}$ medium, were bombarded with tungsten microprojectiles using a biolistic helium particle accelerator (Biomics, Brasília, Brazil). To precipitate DNA onto the microparticles, $8 \mu \mathrm{L}$ plasmid DNA (stock $1 \mu \mathrm{g} \mu \mathrm{L}^{-1}$ ) were added to $50 \mu \mathrm{L}$ tungsten particle $\mathrm{M} 10 / 0.8 \mu \mathrm{m}$ (Sylvania, GTE Chemicals, Towanda, USA) stock solution $\left(60 \mathrm{mg} \mathrm{mL}^{-1}\right)$ under low agitation. A 50\% glycerol sterile solution was used to prepare the tungsten stock solution. Then, $50 \mu \mathrm{L} \mathrm{CaCl}_{2}$ (stock $2.5 \mathrm{M}$ ) and $20 \mu \mathrm{L}$ spermidin (stock $0.1 \mathrm{M}$ ) were added and homogenized. The mixture was kept for three minutes under low agitation and for an additional three minutes without agitation. Particles coated with DNA were centrifuged five seconds at $5,000 \mathrm{~g}$, rinsed carefully three times with $150 \mu \mathrm{L} 100 \%$ ethanol and suspended in $60 \mu \mathrm{L}$ $100 \%$ ethanol. Six microliter aliquots were deposited at the center of sterile Kapton membrane (Ficael, São Paulo, SP) discs $(24 \mathrm{~mm})$ that were used for explant bombardment. Bombardments were performed on 60x15 mm Petri dishes containing 100-150 immature embryos, placed within a $35 \mathrm{~mm}$ diameter circle. A steel net (100 mesh) was placed $50 \mathrm{~mm}$ above the plate with the explants.

Preliminary experiments to test the influence of cultivation of explants in osmoticum media upon transient transformation efficiency were performed. Immature embryos were bombarded without cultivation in an osmoticum medium, or placed on BCI osmotic medium (BCI medium containing 12\% sucrose) during four hours prior to bombardment and transferred to the callus induction media 16 hours after bombardment, or placed on osmotic medium during four hours prior to bombardment and transferred, soon after bombardment to the callus induction medium.

Different treatments were designed to test the pressure of the accelerating helium pulse (650 and $1,100 \mathrm{psi})$, microprojectile flying distance $(6.6,9.9$ and $13.2 \mathrm{~cm})$ and the number of shots per plate (1,2 and 3) in transient and stable maize transformation. The distance between the high pressure chamber and the macrocarrier membrane $(8 \mathrm{~mm})$, the distance between the macrocarrier membrane and the retention screen $(17 \mathrm{~mm})$, and the vacuum pressure $(27 \mathrm{~mm} \mathrm{Hg})$ were maintained constant. Three plates were bombarded for each treatment. 
Selection of putative transformed tissues began 14 days after bombardment when the explants were cultured every two to three weeks on BSM media (BCI media lacking $\mathrm{L}$-proline and casein) containing increasing concentrations $\left(3,6\right.$ and $\left.9 \mathrm{mg} \mathrm{L}^{-1}\right)$ of ammonium glufosinate (4-hidroxi(methyl) phosphynol-DLhomoalanine ammonium salt), the active compound of the commercial herbicide Finale. Regeneration was initiated by placing callus tissue, for two weeks on RM medium - MS salts and vitamins (Murashige \& Skoog, 1962), $60 \mathrm{~g} \mathrm{~L}^{-1}$ sucrose, $100 \mathrm{mg} \mathrm{L}^{-1}$ myo-inositol, $0.2 \mathrm{mg} \mathrm{L}^{-1}$ NAA, $3 \mathrm{~g} \mathrm{~L}^{-1}$ Phytagel, pH 5.8 supplemented with $6 \mathrm{mg} \mathrm{L}^{-1}$ ammonium glufosinate and cultured in the dark at $25^{\circ} \mathrm{C}$ for somatic embryo maturation. Mature somatic embryos showing an opaque coloration were transferred to Magenta boxes containing half strength MS media without plant growth regulators, supplemented with $3 \mathrm{mg} \mathrm{L}^{-1}$ ammonium glufosinate and placed in a lighted (16 hours) growth room. Germinated plantlets $(4-6 \mathrm{~cm})$ were cultured in soil (for the first week under a plastic lid) in a greenhouse.

For the reporter gene uidA transient expression studies, $10 \%$ of bombarded explants were incubated two days after bombardment at $37^{\circ} \mathrm{C}$ for 20 hours in a solution containing $1 \mathrm{mM} 5$-bromo-4-chloro-3-indolyl $\beta$-D glucuronide, $50 \mathrm{mM}$ phosphate buffer $\mathrm{pH} 6.8$, $20 \%$ methanol, $1 \%$ Triton X-100 (Rueb \& Hensgens, 1998). GUS spots were scored using a stereomicroscope Stemi SV11 Zeiss. For calculations of the percentage of transient GUS expression, on each group of treatments, the embryo containing the higher number of blue spots was considered $100 \%$. The percentage of transgenic plants generated was calculated in relation to the number of immature embryos bombarded. Tissue of stable transformed calluses and plants were stained in the same way. After staining, chlorophyll was extracted from leaf tissue in 70\% ethanol for 30-60 min.

Transformed T0 and T1 plants, obtained after self pollination of $\mathrm{T} 0$ plants, were treated, in greenhouse, with the herbicide Finale $\left(1 \mathrm{mg} \mathrm{L}^{-1}\right)$. Plants were scored for herbicide damage seven days after application.

For the molecular characterization of the transgenic plants generated, total genomic DNA was isolated from leaf tissue of primary transformants using a CTAB protocol described by Saghai-Maroof et al. (1984) and submitted to PCR and Southern blot analysis. For the presence of bar, the primers 5'AGA AAC CAC GTC ATG CC and 3'TGC ACC ATC GTC AAC CAC, which amplify a $407 \mathrm{pb}$ product, were used. For the uidA coding region, the primers 5'TCG TGC TGC GTT TCG ATG and 3'GCA TCA CGC AGT TCA ACG were used and the expected product was $406 \mathrm{pb}$ in length. Each $25 \mu \mathrm{L}$ amplification reactions containing $50 \mathrm{ng}$ of template DNA, $5 \mu \mathrm{M}$ each primer, $500 \mu \mathrm{M}$ dNTP mixture, $2.5 \mu \mathrm{L}$ Taq DNA polymerase reaction buffer and 1 unit Taq DNA polymerase. The reactions were carried out using a thermal cycler (Eppendorff Mastercycler) under the following conditions: $94^{\circ} \mathrm{C}$ for $5 \mathrm{~min} ; 30$ cycles $94^{\circ} \mathrm{C}$ for $60 \mathrm{~s} ; 55^{\circ} \mathrm{C}$ for $30 \mathrm{~s}$, and a final extension at $72^{\circ} \mathrm{C}$ for $10 \mathrm{~min}$. The amplified products were separated by electrophoresis on a $1.2 \%$ agarose gel and visualized with ethidium bromide stain under UV light.

For Southern blot analysis, ten micrograms of total genomic DNA from each T0 plant was completely digested with HindIII at $37^{\circ} \mathrm{C}$ overnight, separated by electrophoresis in $0.8 \%$ agarose gel, and then transferred onto a Hybond- $\mathrm{N}^{+}$nylon membrane according to Sambrook et al. (1989). The blot was hybridized with a ${ }^{32} \mathrm{P}$ labeled bar gene coding region. Negative control samples consisted of non-transgenic genomic DNA of L1345 or L3 lines. Hybridized membranes were exposed to Kodak XAR-5 film at $75^{\circ} \mathrm{C}$ for three days.

\section{Results and Discussion}

Genotypic variation is one of the factors that affect plant response under cultivation (Wang et al., 2003). Zygotic maize embryos (Figure $1 \mathrm{~A}$ ), from different cultivars, when cultured in vitro can originate Type I or Type II embryogenic calluses. Type I callus is formed by hard, compact and yellowish tissue, usually able to regenerate plants. Type II callus is soft, friable, highly embryogenic and able to regenerate a higher number of plants than Type I callus (Vasil \& Vasil, 1981; Armstrong \& Green, 1985). Both types of calluses can be used to generate transgenic plants (Brettschneider et al., 1997; Frame et al., 2006). Independently of the maize inbred line used, the majority of callus developed, in N6 salts supplemented culture media in this work, was Type I (Figure $1 \mathrm{~B}$ ). In addition to forming Type I callus, the inbred line L3 was able to form Type II callus at $19 \%$ of frequency (Figure 1 C). Frame et al. (2006) used N6 and MS salts to produce embryogenic callus from different maize cultivars and eight out of the eleven inbred lines used in their report formed Type I callus.

When calluses were subcultured in a medium with elevated sucrose concentrations $\left(60 \mathrm{~g} \mathrm{~L}^{-1}\right)$ and Phytagel $\left(3 \mathrm{~g} \mathrm{~L}^{-1}\right)$ and low temperature $\left(25^{\circ} \mathrm{C}\right)$, a two to three weeks maturation period was essential for high percentage of plant regeneration. Throughout the 
maturation period, somatic embryos lost their shiny aspect and became white and opaque (Figure $1 \mathrm{D}$ ). The germination of the mature somatic embryos occurred within two to three weeks (Figure $1 \mathrm{E}$ and F), while plant regeneration did not occur in most cases from callus that was not submitted to the maturation process.

An important aspect in transformation via biolistics is the damage to the target tissue during microparticle penetration into the cell. To minimize this problem, the target cells are usually plasmolysed by an osmotic treatment (Brettschneider et al., 1997). The elevation of osmotic pressure is generally obtained by the addition of mannitol, sorbitol, maltose or sucrose to the culture medium (Brettschneider et al., 1997; Bohorova et al.,
1999). In this work, a higher number of transient GUS signals was recorded from immature embryos that had been cultured four hours before bombardment on medium with a higher osmolarity and transferred to callus induction medium 16 hours later ( $26.4 \pm 4.33$ blue spots per embryo) than from embryos cultured four hours before bombardment on a higher osmolarity and transferred to callus induction medium soon after bombardment (15.2 \pm 2.17 blue spots per embryo) or from embryos bombarded without osmotic pretreatment $(2.2 \pm 2.17$ blue spots per embryo) (Figure 2). Vain et al. (1993) showed that there was a gain in transient expression when embryos were maintained for more 16 hours after bombardment in high osmotic concentration medium.
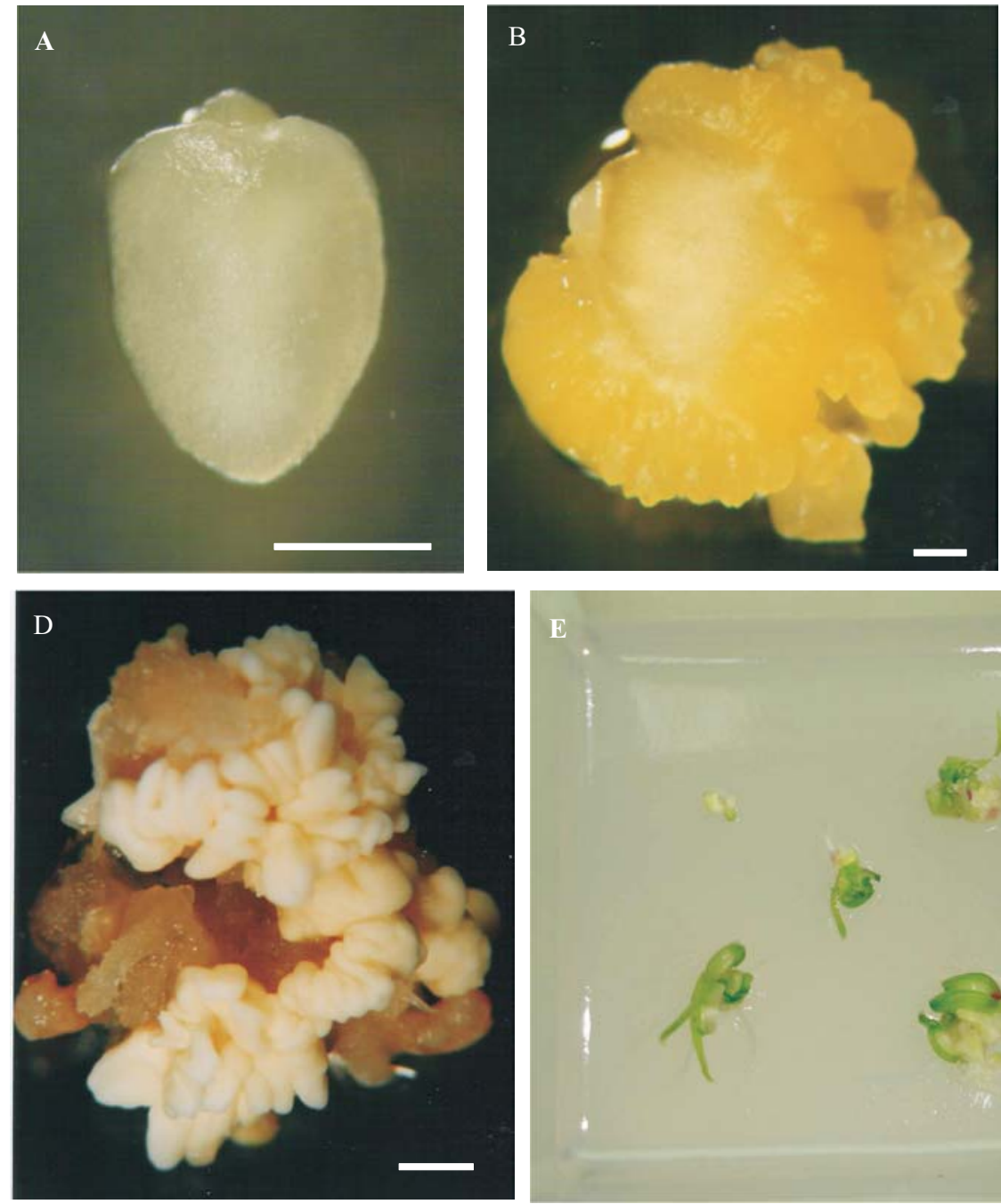
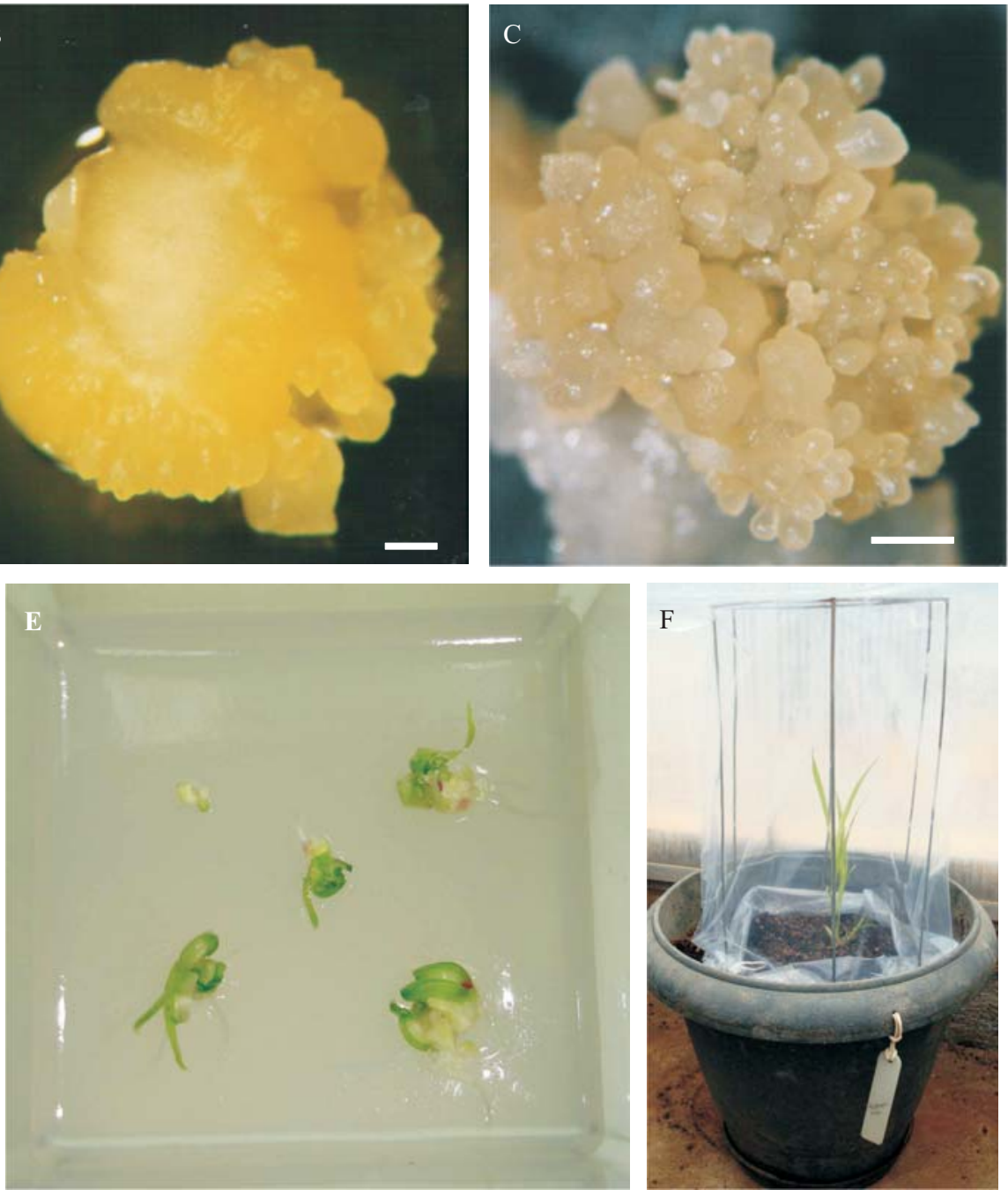

Figure 1. Different stages of Brazilian maize inbred lines tissue culture. A) Immature somatic embryo. B) Type I embryogenic callus from tropical inbred line L1345. C) Type II embryogenic callus from tropical inbred line L3. D) Mature embryos from L1345 (white and opaque structures). E) Germination of calluses from line L1345. F) Regenerated maize plantlet in greenhouse. Scale bar: $1 \mathrm{~mm}$. 
According to Wang et al. (2003), post bombardment osmotic treatments favor a higher recovery of stable events.

Acceleration pressure is another parameter that influences the efficiency of biological ballistics to deliver DNA into various explants. The best results regarding cereal transformation have ranged from $650 \mathrm{psi}$ (Frame et al., 2000) to 1,000 psi (Brettschneider et al., 1997; Bohorova et al., 1999). In this work, transient GUS expression was higher when immature embryos of
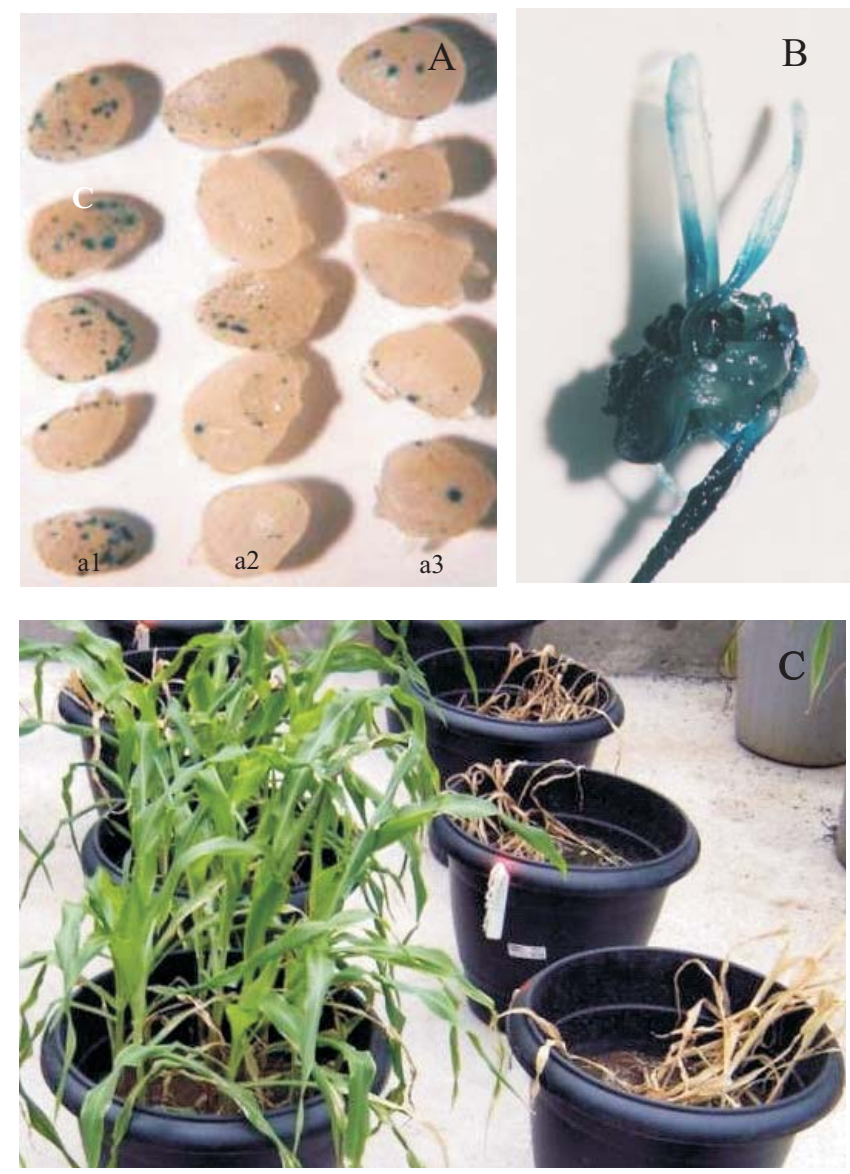

Figure 2. Expression of beta-glucuronidase and phosphinothricin acetyltransferase genes. A) Transient GUS activity visualized in scutellar tissue of line L1345 under different osmotic pretreatments (a1, embryos cultured four hours prior and 16 hours after bombardment in medium containing $12 \%$ sucrose; a2, embryos subcultured four hours prior bombardment in medium containing $12 \%$ sucrose and immediately after bombardment transferred to BSM medium; a3, embryos were bombarded without osmotic treatment). B) Putative transgenic callus and plantlet expressing the uidA reporter gene. C) Transgenic $\mathrm{T} 1$ (left) and non-transgenic control (right) maize plants treated with the herbicide Finale. tropical lines L1345 and L3 were bombarded at 1,100 psi than with 650 psi (Table 1). At 1,100 psi the number of blue foci amounted from nine to 75 per immature embryo bombarded. Stable transgenic plants were produced at a frequency of 0.66 and $1.24 \%$ when embryos of inbred line L1345 genotype were shot at 650 and 1,100 psi, respectively. When inbred line L3 was used, transgenic plants were generated, at a frequency of $1.7 \%$, only when calluses were bombarded at 1,100 psi. A greater number of stable transgenic plants, from L1345 and L3 immature embryos, produced at 1,100 psi helium acceleration pressure may be due to the presence of cells capable of embryogenesis in deeper cell layers as suggested by Brettschneider et al. (1997).

To increase the possibility of hitting a greater number of cells capable to undergo somatic embryogenesis, the influence of more than one shot per plate was tested. More than one consecutive shot on the same plate resulted in increased GUS transient expression (Table 1). Two shots per plate produced 2.31 and $0.9 \%$ of transgenic plants from inbred lines L3 and L1345, respectively, while there were no transgenic plants produced when three shots were used. Three shots per plate probably caused more injury to the explants, which impaired cell proliferation and regeneration. Reggiardo et al. (1991) found that more than one bombardment per plate had deleterious effects on barley and maize cells. However, in wheat, Wang et al. (1988) observed a direct relationship between an increase in the number of cells transiently expressing GUS and an increase in the number of shots per plate.

Table 1. Transient expression of GUS on the surface of zygotic immature embryos from maize tropical inbred lines L1345 and L3 under different biolistic conditions.

\begin{tabular}{|c|c|c|}
\hline \multirow[t]{2}{*}{ Particle bombardment parameters } & \multicolumn{2}{|c|}{$\%$ Transient GUS expression ${ }^{(1)}$} \\
\hline & L3 & L1345 \\
\hline \multicolumn{3}{|l|}{ Helium acceleration pressure ${ }^{(2)}$} \\
\hline $650 \mathrm{psi}$ & $31.67 \pm 3.1$ & $28.60 \pm 2.74$ \\
\hline $1,100 \mathrm{psi}$ & $56.73 \pm 4.28$ & $49.38 \pm 5.14$ \\
\hline \multicolumn{3}{|l|}{ Number of shots per plate ${ }^{(3)}$} \\
\hline 1 & $30.98 \pm 3.82$ & $24.4 \pm 5.71$ \\
\hline 2 & $67.93 \pm 7.27$ & $46.37 \pm 6.14$ \\
\hline 3 & $69.02 \pm 8.7$ & $44.34 \pm 5.65$ \\
\hline \multicolumn{3}{|l|}{ Microcarrier flying distance $^{(4)}$} \\
\hline $6.60 \mathrm{~cm}$ & $57.61 \pm 3.42$ & $47.29 \pm 5.04$ \\
\hline $9.90 \mathrm{~cm}$ & $44.81 \pm 2.37$ & $41.51 \pm 3.66$ \\
\hline $13.20 \mathrm{~cm}$ & $25.19 \pm 1.58$ & $20.23 \pm 2.37$ \\
\hline
\end{tabular}

${ }^{(1)} \mathrm{SE}$ of at least 20 embryos. ${ }^{(2)}$ Constant conditions: microcarrier flying distance of $6.60 \mathrm{~cm}$ and one shot per plate. ${ }^{(3)}$ Constant conditions: microcarrier flying distance of $6.60 \mathrm{~cm}$ and $1,100 \mathrm{psi}$ helium accelerating pressure. ${ }^{(4)}$ Constant condition: one shot per plate and 1,100 psi helium accelerating pressure. 
The distance from the microprojectile launch site to the biological target can affect the velocity of microprojectiles and consequently transformation rates. A higher number of expression units were detected when explants were placed $6.6 \mathrm{~cm}$ away from the launch platform, followed by 9.9 and $13.2 \mathrm{~cm}$ (Table 1). At $6.6 \mathrm{~cm}$, higher number of transgenic plants was generated than at 9.9 and $13.2 \mathrm{~cm}$, which correlated with the transient expression results obtained. At 9.9 and $13.2 \mathrm{~cm}$ no transgenic events were observed for these tropical genotypes. Tadesse et al. (2003) reported a higher number of transient GUS expression as well as stable transformation events at a microcarrier flying distance of $6 \mathrm{~cm}$ than at $12 \mathrm{~cm}$.

Thirty seven putative transformed maize plants (12 from line L1345 and 25 from line L3) obtained using the different parameters tested in this work, were transferred to pots containing soil and grown under greenhouse conditions. Three weeks after being transplanted to greenhouse, T0 plants were sprayed with the herbicide Finale to test the expression of the introduced bar gene. Seven days after herbicide application, 31 plants with transgenic events showed resistance to the herbicide Finale, while the nontransformed escapes and controls presented leaf necrosis and died (Figure 2). False positive plants surviving the selection process have been reported previously and could be the result of a non-stable integration of the transgene into the plant genome (Huang \& Wei, 2005). Twenty-eight herbicide tolerant plants developed normally and flowered. From all these lines, plants resistant to herbicide were recuperated after treatment of germinated T1 seeds with Finale in greenhouse. The transgene was stably integrated into the genome of the transgenic lines generated.

PCR analysis was conducted on all of the 37 plants regenerated from immature embryo transformation. It was observed $406 \mathrm{bp}$ band of uidA and $407 \mathrm{bp}$ band of bar genes in 29 and 31 plants, respectively (Figure 3). Similar results were reported by El-Itriby et al. (2003), who showed that few of the plants tested positive for herbicide tolerance did not show the uidA fragment, demonstrating that the gene has been deleted.

Southern blot of total DNA from transgenic plants digested with HindIII and probed with bar gene showed that glufosinate resistant plants contained from one to ten copies of the transgene (Figure 4). Co-expression of the linked genes (bar and uidA) was detected in 21 out of the 31 plants analyzed. Eight herbicide resistant plants, that contain the uidA gene, did not produce

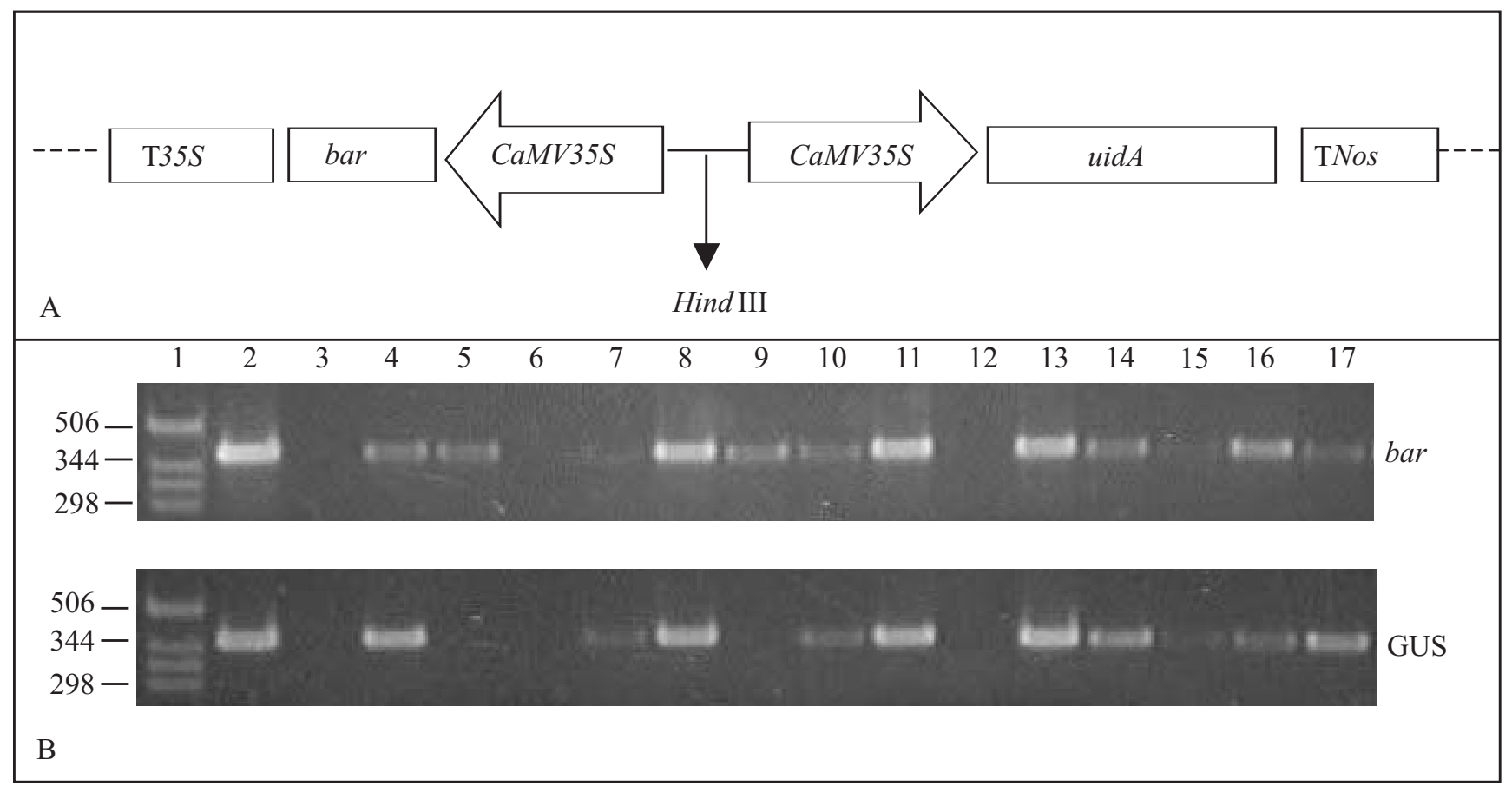

Figure 3. CAMBIA 3301 vector and PCR analyses of maize T0 transformants. A) CAMBIA vector bar: phosphinothricin acetyltransferase gene. CaMV35S: cauliflower mosaic virus promoter. T35S: terminator from CaMV35S. TNos: terminator from nopaline synthase gene. uidA: beta-glucuronidase gene containing an intron. B) Total DNA from 14 regenerated plants were amplified using bar and uidA primers. Lane 1: molecular marker. Lane 2: PCR amplification of positive control CAMBIA 3301. Lane 3: DNA from non-transformed plant. Lanes 4 to 17: DNA from transformed maize plants. 


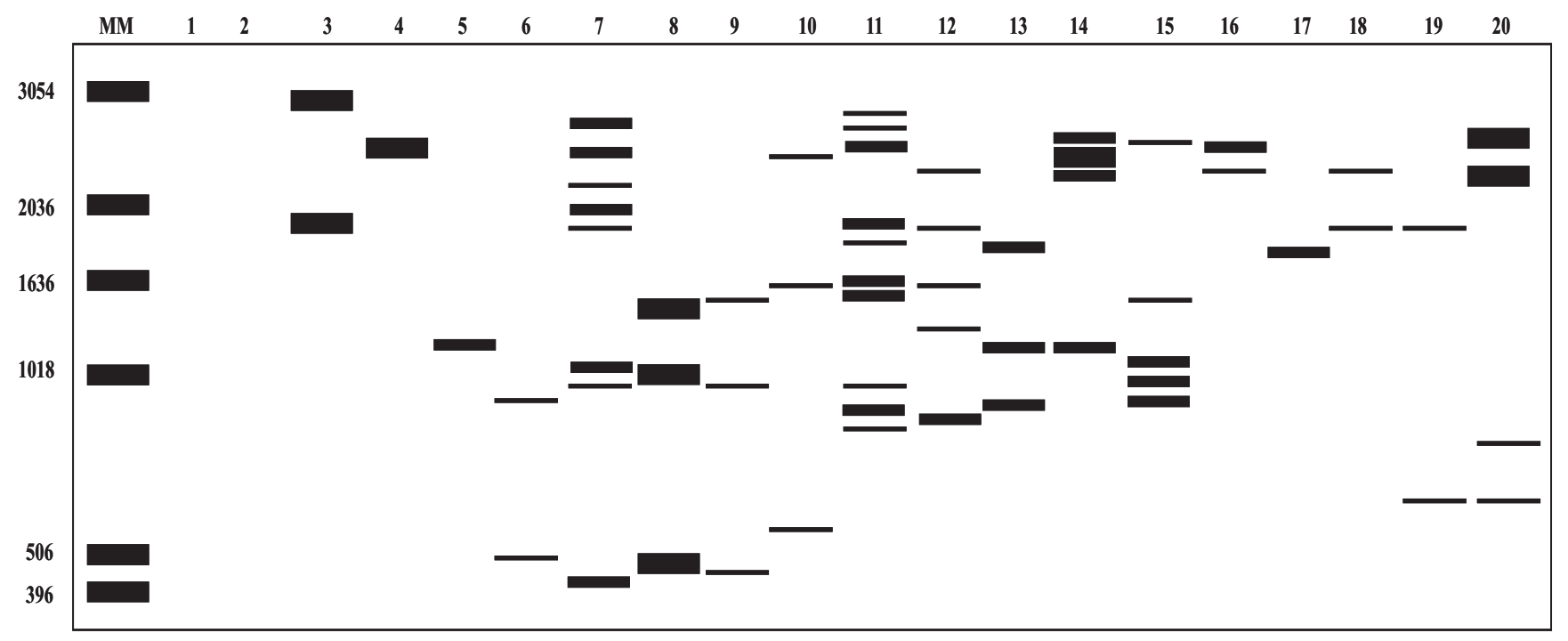

Figure 4. DNA blot of pCAMBIA 3301 T0 plants. Hind III digested DNA probed with bar coding sequence and electrophoresed on $0.8 \%$ agarose. MM: molecular marker. Lanes 1 and 2: control non-transformed maize L3 and L1345 plants. Lanes 3 to 20 : putative transformed maize plants with different transgene copy numbers. Lanes 3 to 9: inbred line L1345. Lanes 10 to 20: inbred line L3.

beta-glucuronidase. Silence of transgenes throughout DNA methylation has been described by Emani et al. (2002). Register et al. (1994) reported that rearrangements could occur, if the transgene expression is not under selection pressure.

The molecular and expression analysis of the introduced bar and uidA genes confirmed the integration and expression of the transgene into the maize plants generated.

\section{Conclusions}

1. Zygotic immature embryos from maize inbred lines L3 and L1345 are able to form embryogenic calluses and regenerate plants in vitro.

2. Particle bombardment is an effective technology to produce transgenic maize tropical lines.

3. The protocol utilized may be useful to introduce agronomical important genes into tropical maize lines.

\section{Acknowledgements}

To Raymundo Diniz, for tissue culture technical support; to Embrapa, Promoagro, Conselho Nacional de Desenvolvimento Científico e Tecnológico, Fundação de Amparo à Pesquisa do Estado de Minas Gerais, International Atomic Energy Agency, Programa de Apoio ao Desenvolvimento Científico e Tecnológico, Programa de Apoio a Núcleos de Excelência, for financial support; to Coordenação de Aperfeiçoamento de Pessoal de Nível Superior, for scholarship support.

\section{References}

ARMSTRONG, C.L.; GREEN, C.E. Establishment and maintenance of friable, embryogenic maize callus and the involvement of L-proline. Planta, v.164, p.207-214, 1985.

BOHOROVA, N.; ZHANG, W.; JULSTRUM, P.; McLEAN, S.; LUNA, B.; BRITO, R.M.; DIAZ, L.; RAMOS, M.E.; ESTANOL, P.; PACHECO, M.; SALGADO, M.; HOISINGTON, D. Production of transgenic tropical maize with $c r y I A b$ and $c r y I A c$ genes via microprojectile bombardment of immature embryos. Theoretical and Applied Genetics, v.99, p.437-444, 1999.

BRETTSCHNEIDER, R.; BECKER, D.; LÖRZ, H. Efficient transformation of scutellar tissue of immature maize embryos. Theoretical and Applied Genetics, v.94, p.737-748, 1997.

CARNEIRO, A.A.; CARNEIRO, N.P.; CARVALHO, C.H.S.; VASCONCELOS, M.J.V.; LOPES, M.A.; PAIVA, E. Milho transgênico: melhoria da qualidade nutricional do grão. Biotecnologia, v.15, p.42-46, 2000.

CARVALHO, C.H.S.; BOHOROVA, N.E., BORDALLO, P.N.; ABREU, L.L.; VALICENTE, F.H.; BRESSAN, W.; PAIVA, E. TypeII callus production and plant regeneration in tropical maize genotypes. Plant Cell Reports, v.17, p.73-76, 1997.

CHU, C.C.; WANG, C.C.; SUN, C.S.; HSU, C.; YIN, K.C.; BI, C.V. Establishment of an efficient medium for anther culture of rice through comparative experiments on the nitrogen source. Scientia Sinica, v.18, p.659-668, 1975. 
EL-ITRIBY, H.; ASSEM, S.K.; HUSSEIN, E.H.A.; ABDEL-GALIL, F.M.; MADKOUR, M.A. Regeneration and transformation of Egyptian maize inbred lines via immature embryo culture and a biolistic particle delivery system. In Vitro Cellular and Developmental Biology - Plant, v.39, p.524-531, 2003.

EMANI, C.; SUNILKUMAR, G.; RATHORE, K.S. Transgene silencing and reactivation in sorghum. Plant Science, v.162, p.181-192, 2002.

FRAME, B.R.; McMURRAY, J.M.; FONGER, T.M.; MAIN, M.L.; TAYLOR, K.W.; TORNEY, F.J.; PAZ, M.M.; WANG, K. Improved Agrobacterium-mediated transformation of three maize inbred lines using MS salts. Plant Cell Reports, v.25, p.10241034, 2006

FRAME, B.R.; ZHANG, H.; COCCIOLONE, S.M.; SIDORENKO, L.V., DIETRICH, C.R.; PEGG, S.E.; ZHEN, S.; SCHNABLE, P.S.; WANG, K. Production of transgenic maize from bombarded type II callus: effect of gold particle and callus morphology on transformation efficiency. In Vitro Cellular Developmental Biology - Plant, v.36, p.21-29, 2000.

HERRERA-ESTRELLA, L.; SIMPSON, J.; MARTINEZTRUJILLO, M. Transgenic plants: an historical perspective. Methods of Molecular Biology, v.286, p.3-32, 2005.

HUANG, X.; WEI, Z. Successful Agrobacterium-mediated genetic transformation of maize elite inbred lines. Plant Cell, Tissue and Organ Culture, v.83, p.187-200, 2005.

JEFFERSON, R.A. Assaying chimeric genes in plants: the GUS gene fusion system. Plant Molecular Biology Reporter, v.5, p.387-405, 1987.

JEOUNG, J.M.; KRISHNAVENI, S.; MUTHUKRISHNAN, S.; TRICK, H.N.; LIANG, G.H. Optimization of sorghum transformation parameters using genes for green fluorescent protein and $\beta$-glucuronidase as visual markers. Hereditas, v.137, p.20-28, 2002.

KLEIN, T.M.; FROMM, M.E.; WEISSINGER, A.; TOMES, D.; SCHAAF, S.; SLETTERN, M.; SANFORD, J.C. Transfer of foreign genes into intact maize cells using high velocity microprojectiles. Proceedings National Academy of Science of the United States of America, v.85, p.4305-4309, 1988.

LORENCE, A.; VERPOORTE, R. Gene transfer and expression in plants. In: TUAN, R.S. Recombinant gene expression: reviews and protocols. $2^{\text {nd }}$ ed. Totowa: Humana Press, 2004. p.329-350.

MURASHIGE, T.; SKOOG, F. A revised medium for rapid growth and bioassays with tobacco tissue cultures. Physiologia Plantarum, v.15, p.473-497, 1962.
REGGIARDO, M.I.; ARANA, J.L.; ORSARIA, L.M.; PERMINGEAT, H.R.; SPITTELER, M.A.; VALLEJOS, R.H. Transient transformation of maize tissues by microparticle bombardment. Plant Science, v.75, p.237-243, 1991.

REGISTER, J.C.; PETERSON, D.J.; BELL, P.J.; BULLOCK, W.P.; EVANS, I.J.; FRAME, B., GREENL, A.J.; HIGGS, N.S.; JEPSON, I.; JIAO, S.; LEWNAU, C.J.; SILLICK, J.M.; WILSON, M. Structure and function of selectable and non-selectable transgenes in maize after introduction by particle bombardment. Plant Molecular Biology, v.25, p.951-961, 1994.

RUEB, S.; HENSGENS, L.A.M. Improved histochemical staining for $\beta$-glucuronidase activity in monocotyledonous plants. Rice Genetic Newsletters, v.6, p.168-169, 1998.

SAGHAI-MAROOF, M.A.; SOLIMAN, K.M.; JORGENSEN, R.A.; ALLARD, R.W. Ribosomal DNA spacer-length polymorphisms in barley: Mendelian inheritance, chromosomal location, and population dynamics. Proceedings National Academy of Science of the United States of America, v.81, p.8014-8018, 1984.

SAMBROOK, J.; FRITSCH, E.F.; MANIATIS, T. Molecular cloning: a laboratory manual. $2^{\text {nd }}$ ed. New York: Cold Spring Harbor Laboratory Press., 1989.

TADESSE, Y.; SÁGI, L.; SWENNEN, R.; JACOBS, M. Optimisation of transformation conditions and production of transgenic sorghum (Sorghum bicolor) via microparticle bombardment. Plant Cell, Tissue and Organ Culture, v.75, p.1-18, 2003.

VAIN, P.; McMULLEN, M.D.; FINER, J.J. Osmotic treatment enhances particle bombardment-mediated transient and stable transformation of maize. Plant Cell Reports, v.12, p.84-88, 1993.

VASIL, V.; VASIL, I.K. Somatic embryogenesis and plant regeneration from tissue cultures of Pennisetum americanum and $P$. americanum x P. purpureum hybrid. American Journal of Botany, v.68, p.864-872, 1981.

WANG, K.; FRAME, B.; MARCELL, L. Genetic transformation of maize. In: JAIWAL, P.K.; SINGH, R.P. (Ed.). Plant genetic engineering: improvement of food crops. Houston: Sci Tech Publishing LLC, 2003. v.2. p.175-216.

WANG, Y.C.; KLEIN, T.M.; FROMM, M.; CAO, J.; SANFORD, J.C.; WU, R. Transient expression of foreign genes in rice, wheat and soybean cells following particle bombardment. Plant Molecular Biology, v.11, p.433-439, 1988.

Received on August 15, 2007 and accepted on February 18, 2008 